\title{
Strategi Pengembangan Obyek Wisata Negeri Dongeng Sebagai Destinasi Wisata Unggulan Berbasis Taman Wisata Miniatur Tempoe Doeloe
}

\author{
Strategy of Development Fairyland Tourism Object as Leading Tourist Based \\ Destination Tempoe Doeloe Miniature Park
}

\author{
Eko Adi Susilo S.E., M.M' ${ }^{1}$, Lu'lu UI Maknunah S.Tp, M.P \\ ${ }^{1}$ Fakultas Ilmu Sosial dan Ilmu Politik, Univ. Islam Balitar \\ Jl. Majapahit No. 2 - 4, Blitar, Indonesia \\ ${ }^{2}$ Fakultas Ilmu Sosial dan Ilmu Politik, Univ. Islam Balitar \\ Jl. Majapahit No. 2 - 4, Blitar, Indonesia \\ Email: adisusiloeko@gmail.com
}

\begin{abstract}
ABSTRAK
Pariwisata merupakan salah satu aset besar yang dapat menghasilkan sumber devisa yang cukup tinggi bagi negara. Maka dari itu disetiap daerah yang memiliki obyek wisata tertentu, memerlukan pengembangan wisata yang berkala dan berkelanjutan sehingga masyarakat dapat mengambil manfaat dari adanya destinasi wisata di daerah tersebut. Seperti halnya obyek Wisata Negeri Dongeng yang berada di daerah Desa Kawedusan Ponggok Kabupaten Blitar. Desain pembuatan wisata ini bertajuk taman miniatur bangunan keajaiban dunia yang menarik untuk dikunjungi sebagai wahana edukasi bagi anak- anak. Masyarakat dapat memanfaatkan ini sebagai media pembelajaran dan nantinya akan berdampak luas bagi masyarakat sekitar lokasi ini untuk menghidupkan sektor perekonomian. Penelitian ini bertujuan untuk; (1) Mengidentifikasi kondisi aktual aspek pengembangan Obyek Wisata Negeri Dongeng saat ini. (2) Mengidentifikasi pengaruh adanya obyek wisata Negeri Dongeng sebagai wahana rekreasi terhadap wisatawan pengunjung dan masyarkat sekitar Desa Kawedusan Ponggok. (3) Menyusun strategi pengembangan obyek wisata Negeri Dongeng sebagai wahana rekreasi berbasis taman wisata tempoe doeloe. Metode Penelitian yang digunakan oleh penulis dalam penelitian ini adalah penelitian kualitatif dan menggunakan pendekatan bersifat analisis deskriptif. Hasil dari penelitian ini dengan menggunakan teknik analisis SWOT dapat disimpulkan bahwa strategi pengembangan wisata negeri dongeng memperlihatkan bahwa proses identifikasi indikator yang relevan diharapkan mampu memberikan manfaat dalam merumuskan strategi pengembangan wisata Negeri Dongeng di Kabupaten Blitar. Dengan ini wisata negeri dongeng diharapkan dapat bersaing atas konsep yang ditawarkan dan akan memberikan penguatan ekonomi sekaligus kesejahteraan masyarakat sekitar
\end{abstract}

Kata Kunci : Strategi Pengembangan, Wisata, Negeri Dongeng

ABSTRACT

Tourism is one of the major assets that can generate a fairly high source of foreign exchange for the country. Therefore, every area that has certain tourism 
objects requires regular and sustainable tourism development so that people can take advantage of the existence of tourist destinations in the area. As with the tourism object of the Land of Fairy tales in the area of Kawedusan Ponggok Village, Blitar Regency. The design of this tour is entitled the miniature garden of the wonders of the world which is interesting to visit as a vehicle for education for children. The community can use this as a learning medium and it will have a broad impact on the people around this location to revive the economic sector. This research aims to; (1) Identifying the actual conditions of the current development aspects of the Land of Fairy Tales Tourism. (2) Identifying the influence of the tourism object of the Land of Tales as a vehicle for recreation on tourist visitors and the community around Kawedusan Ponggok Village. (3) Formulating a strategy to develop tourism objects in the Land of Tales as recreational vehicles based on the Tempoe Doeloe tourism park. The research method used by the author in this study is qualitative research and uses a descriptive analysis approach. The results of this study using SWOT analysis techniques can be concluded that the fairy tale tourism development strategy shows that the process of identifying relevant indicators is expected to be able to provide benefits in formulating a tourism development strategy for the Land of Tales in Blitar Regency. Through the formulation of a tourism strategy in a fairy tale country, it is hoped that it will be able to provide benefits to strengthening the competitive bidding position of the concepts offered. It is hoped that this will also be able to provide benefits to strengthening the economic and social aspects of the community at large.

Keywords: Development Strategy, Tourism, Fairy Tale

\section{PENDAHULUAN}

Kabupaten Blitar merupakan wilayah yang terletak di barat Kota Malang Provinsi Jawa Timur. Wilayah ini terkenal cukup popular dengan destinasi baik wisata sejarah maupun wisata alamnya. Wisata terbaru saat ini yang ada di Blitar yaitu wisata edukasi Negeri Dongeng. Di lokasi ini wisatawan akan menemukan suasana yang berbeda. Tidak hanya untuk sebagai tempat wisata, tetapi juga sebagai sarana edukasi untuk anak- anak tempat belajar yang menarik. Wisata ini dilengkapi dengan fasilitas lengkap, lokasi yang strategis dan harga tiket yang relatif murah menjadi alasan yang tepat untuk mengunjungi tempat ini. Tempat ini dijuluki sebagai wisata negeri dongeng, karena pengunjung memang akan merasa seperti di negeri dongeng dengan miniatur bangunan sejarah di dunia.

Dalam perkembangannya selama ini, wisata Negeri Dongeng banyak diminati oleh para pengunjung yang datang di lokasi ini. Wisata ini tidak hanya sekedar sebagai tempat hiburan, tetapi juga dapat digunakan oleh masyarakat 
untuk menggali ilmu melalui desain bangunannya yang diorientasikan pada pengembangan wawasan sejarah. Inilah yang menjadi keunggulan yang akan digali dan dikembangkan untuk menjadi wisata unggulan di wilayah Kota Blitar. Dengan melihat potensi yang ada, maka perlu perhatian bagi semua pihak untuk ikut berpartisipasi dengan aktif dalam melestarikan dan menjaga wisata ini dengan baik.

Terlepas dari keunggulan yang dimiliki, wisata ini juga memiliki berbagai kendala yang dimiliki mulai dari pengelolaan, management, operasional dan lain sebagainya. Melihat kondisi seperti itu maka, strategi pengembangan obyek wisata Negeri Dongeng di Desa Kawedusan Ponggok ini perlu dilakukan agar destinasi wisata ini dapat memberikan dampak positif bagi kehidupan masyarakat setempat. Perencanaan dan penyelesaian masalah dalam pariwisata harus diselesaikan secara komprehensif dan terintegrasi dengan melibatkan berbagai sektor.

\section{METODE PENELITIAN}

Obyek Penelitian ini dilakukan di wilayah Kabupaten Blitar, Kecamatan Ponggok Desa Kawedusan dengan objek penelitian yaitu Strategi Pengembangan Wisata Negeri Dongeng Sebagai Destinasi Unggulan Wisata Berbasis Taman Miniatur Tempoe Doeloe. Penelitian ini pengambilan subjek penelitian adalah Pengelola Wisata, dan masyarakat yang berkecimpung dalam pariwisata baik para wisatawan maupun masyarakat lokal. Metode penelitian yang digunakan oleh peneliti dalam penelitian ini adalah penelitian kualitatif.

Penelitian ini bertujuan untuk menjelaskan dan mengungkapkan informasi secara empiris dan obyektif sesuai situasi di lapangan. Penelitian ini juga bersifat deskriptif dengan proses menganalisis dan menjelaskan tentang keadaan dengan pemaparan yang jelas dan naratif dengan data yang akurat. Fokus peneliti dalam riset ini yaitu menentukan strategi pengembangan Wisata Negeri Dongeng di Kecamatan Ponggok Blitar dengan berorientasikan pada wahana edukasi dan rekreasi dalam upaya meningkatkan wisatawan yang berkunjung dan peningkatan sector ekonomi.

Dalam penelitian ini untuk mendapatkan keabsahan data dilakukan dengan 
Triangulasi. Penelitian ini bertujuan untuk merumuskan Strategi Pengembangan Obyek Wisata Negeri Dongeng Sebagai Destinasi Unggulan Wisata Berbasis Taman Miniatur Tempoe Doeloe. Responden pada penelitian ini adalah responden yang dianggap expert dan menguasai materi terkait dengan ruang lingkup Wisata Negeri Dongeng ini dan responden yang dihimpun secara acak di lokasi tempat wisata.

Sumber data yang digunakan yaitu data primer (sesuai dengan fakta empirik). Sumber data diperoleh secara langsung dari survey lapangan dan data sekunder didapat dari berbagai sumber, seperti buku referensi, internet, media massa, dan dokumentasi informasi dari instansi terkait dan literatur penunjang lainnya. Teknik pengumpulan data merupakan aspek penting dalam menentukan keberhasilan penelitian. Pada penelitian ini pengumpulan data menggunakan observasi, wawancara, dan dokumentasi. Sumber data yang diperoleh menggunakan data primer yaitu pegawai dan pengelola wisata negeri dongeng sendiri, sedangkan data sekunder di dapat melalui internet, media masa dan dokumentasi dari wisata terkait.

Analisis SWOT digunakan untuk memperoleh formulasi strategi yang tepat untuk pengembangan Wisata Negeri Dongeng, dengan melakukan identifikasi terhadap sector internal dan sektor eksternal di sekitar kawasan wisata Negeri Dongeng. Faktor strategis internal dimaksudkan untuk mendapatkan sector kekuatan (strength) yang akan digunakan dan sector kelemahan (weakness) yang akan diantisipasi. Faktor strategis eksternal dilakukan untuk mengembangkan sector peluangn (opportunities) yang dapat dimanfaatkan dan sector ancaman (threaths) yang perlu dihindari. Hal ini dilakukan untuk mengetahui pemetaan dan prediksi terkait strategi yang akan dilakukan untuk pengembangan wisata Negeri Dongeng agar memperoleh hasil yang efektif.

Gambar 1. Matrik Analisis SWOT

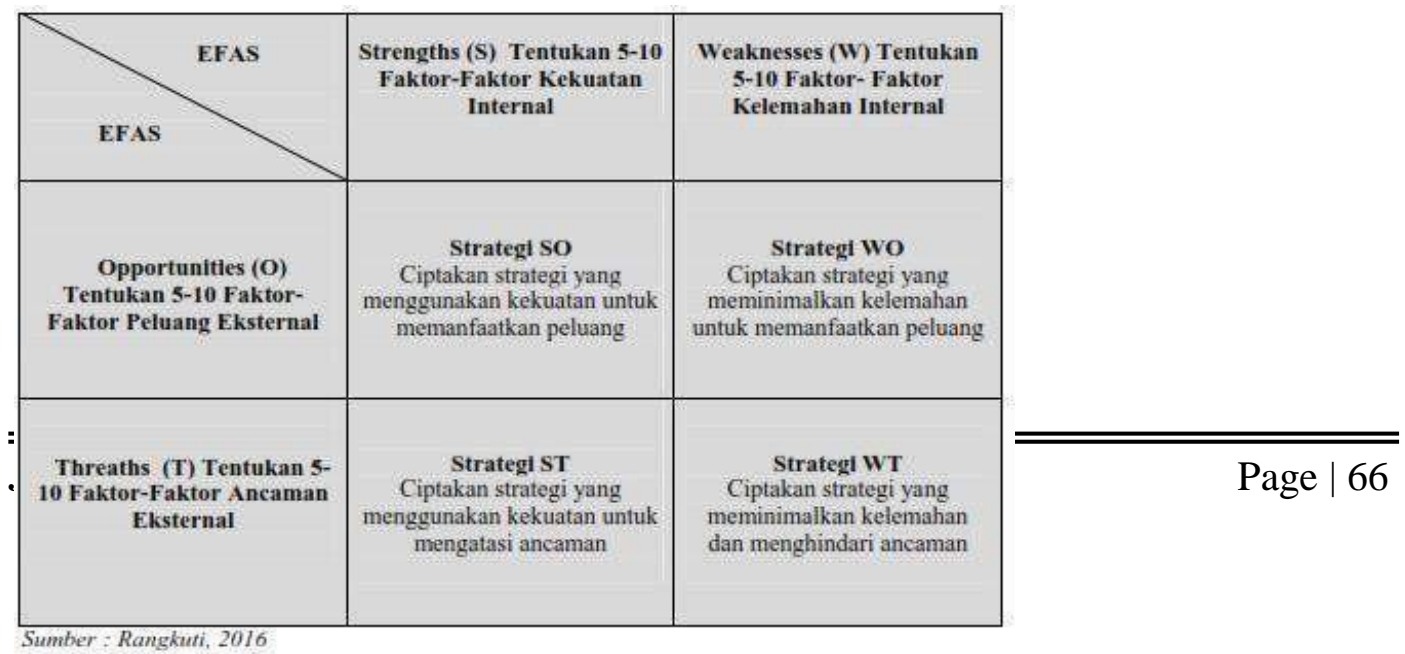




\section{HASIL DAN PEMBAHASAN}

\section{A Kondisi Aktual Pengembangan Obyek Wisata Negeri Dongeng}

Wisata negeri dongeng ini dibuka sekitar tanggal 16 desember 2017 dengan kepemilikan swasta perorangan yang bernama Mohammad Imron Kanafi. Rumah beliau ada di daerah desa Tanggung Kota Blitar. Adapun kepemilikan seperti wahana permainan ini berbeda orang. Wahana permainan ini yang punya atas nama Handoko yang mengelola managernya yaitu atas nama Widodo. Wisata ini berdiri hampir sekitar 3 tahun dengan konsep tema wisata 7 keajaiban dunia.

Awal wisata ini berdiri sebenarnya datang dari pengalaman perjalan ke luar kota. Pada akhirnya dari situ ketemu ide untuk membuat wisata yang belum pernah ada di wilayah Blitar Raya dan di Karisidenan. Pada situasi inilah muncul pembuatan wisata dengan konsep Negeri Dongeng yang memiliki nilai edukasi dan rekreasi.

Awalnya lahan negeri dongeng ini adalah lahan bengkok tanah ladang warga setempat, jadi sistemnya bagi hasil. Dengan rincian $75 \%$ ke pengelola wisata dan $25 \%$ ke desa. Dulunya sawah warga yang dikelola sendiri, akan tetapi hasilnya kurang maksimal. Maka dari itu pihak desa sendiri akhirnya menyerahkan ke pihak Negeri Dongeng sendiri untuk mengelolanya agar hasilnya lebih maksimal. Di dalam area wisata ini juga ada banyak pohon belimbing dari tanaman warga yang mencoba dikombinasikan dengan wahana permainan Negeri Dongeng, sehingga terkesan lebih natural. Pohon belimbing sendiri juga difungsikan untuk memberikan pelatihan kepada pengunjung terkait produksi tanaman belimbing sendiri.

Di wisata negeri dongeng ini ada beberapa wahana yang bisa dinikmati oleh pengunjung yaitu; Spot Selfie yang di awal 2017 itu masih ngetrend. Ada banyak lagi spot yang menarik untuk dinikmati. Terkait pembangunan wisata ini terus berupaya mengalami pengembangan baik wahana, sarana prasarana maupun pelayanan agar wisata ini bisa tetap bersaing dengan wisata lainnya yang ada 
khususnya di Kota Blitar. Ada beberapa spot yang sekarang terus dibangun yaitu taman depan yang terus dibenahi, Spot Selfie dan Outbondnya juga belum selesai yang rencananya ada target tahun depan.

Terkait dengan situasi kondisi pandemik seperti ini memang sangat berpengaruh terhadap banyaknya jumlah pengunjung yang datang. Negeri Dongeng sendiri juga sedikit banyak mengalami kerugian dalam hal pemasukan hampir separuh dari situasi normal pendapatan yang di dapatkan oleh pengelola wisata ini sendiri. Menurut salah satu pengelola di sektor marketing, Mas Agung mengatakan bahwa pada situasi pandemi seperti ini wisata negeri dongeng sendiri mengalami pengurangan jumlah pegawai, karena memang kondisi pemasukan dari wisata ini mengalami kerugian. Rencana dalam pengembangan wisata ini ada penambahan atau perluasan lahan untuk Outbondnya dan rencananya juga akan dibuatkan minimarket sebagai tempat perbelanjaan tepatnya di utara lokasi wisata ini. Di sebelah barat akan dibuatkan tempat seperti kerajaan kurcaci sebagai wahana spot selfie tambahan. Lokasi ini sangat strategis, karena di sekitar pemandangannya terdapat area persawahan, sehingga menunjang untuk dijadikan spot selfie.

Menurut salah satu pengelola di bidang marketing, wisata negeri dongeng ini sudah cukup bertahan sekitar 7 bulan dengan kondisi keuangan yang minim. Saat ini jumlah pegawai yang masih aktif hanya sekitar 10 orang dengan total sebelumnya sekitar 35 pegawai. Awal tutupnya wisata ini karena pandemik yaitu pertengahan bulan maret sampai bulan Agustus sesuai rekomendasi Bupati Blitar. Dengan kondisi seperti ini agar sektor pariwisata di wilayah Blitar tetap berjalan, maka atas kesepakatan berbagai pihak baik pemerintah daerah, Muspika, Kapolres dan stakeholder lainnya boleh melakukan operasional tapi dengan syarat Protokol Kesehatan tetap dijaga.

\section{B. Pengaruh Adanya Obyek Wisata Negeri Dongeng bagi berbagai pihak}

Pengaruh terkait dengan adanya obyek wisata negeri dongeng terhadap masyarakat setempat adalah secara tidak langsung akan meningkatkan penghasilan dan partisipasi warga sekitar untuk terlibat di dalam kegiatan dan dapat terjalin kerjasama dengan pihak pengelola negeri dongeng. Selain itu memang tanah yang dipakai sebagai wisata negeri dongeng sendiri adalah tanah 
warga awalnya yang kemudian disewakan kepada perseorangan pihak swasta untuk dijadikan wisata rekreasi dan edukasi agar mendapat manfaat lebih. Melihat kondisi yang ada disekitar wilayah wisata itu juga terdapat area persawahan yang indah dan menarik untuk dijadikan pemandangan.

Terkait dengan pengaruhnya terhadap masyarakat, banyak sekali sejumlah hal positif yang diambil sebagai ikon dari desa setempat. Sesungguhnya desa yang yang baik adalah desa yang masyarakatnya bisa berfikir luas dan kreatif untuk memunculkan ide-ide baru yang belum pernah ada sebelumya. Ketika sebuah desa dapat menciptkan suatu keunggulan dengan memanfaatkan sumber daya alamnya maka desa itu akan memperoleh sailnya apabila dimanfaatkan secara maksimal Maka dari tiu dengan adanya kerja sama dan pembagian hasil wisata ini dapat dilestarikan dengan kerjasama antara pihak desa dengan pengelola wisata untuk bersinergi membangun wisata ini untuk tetap bertahan dan mengalami kemajuan.

Terkait dengan pengaruhnya terhadap pemerintah daerah, secara umum dapat meningkatkan citra dan perkembangan wisata di daerah tersebut untuk terus mendapat dukungan dari pemerintah daerah sebagai upaya untuk meningkatkan pendapatan daerah. Selain itu dengan banyaknya wisata ini dapat menunjang dan pendapatan kas daerah dan mendapatkan banyak penghargaan terkait dengan kemajuan potensi yang ada di wilayahnnya. Sering juga perwakilan dari masingmasing sektor pariwisata di kota Blitar mengadakan agenda rutin seperti mengadakan event, rapat koordinasi, dan mengadakan kunjungan ke luar daerah untuk studi banding, yang tujuannnya untuk menjalin koordinasi dan mensinergikan agar sektor pariwisata di Blitar dapat terintegrasi dan saling menguntungkan satu sama lain. Adapun terobosan yang dilakukan salah satunya adalah menawarkan fasilitas dan paket rekreasi satu paket dengan biaya yang murah, sehingga setiap wisata juga akan memperoleh keuntungan secara bersamasama.

Bagi pengelola sendiri sangat beruntung dapat dan diperbolehkan untuk memanfaatkan lahan dan fasilitas yang ada. Tentunya dalam jangka panjang apabila wisata ini mengalami proses pembangunan secara terus-menerus akan dapat membawa keuntungan yang besar bagi pemilik dan pengelola secara pribadi dan dapat mendapatkan hasil yang cukup lumayan terhadap masyarakat di sekitar 
desa setempat. Tinggal bagaimana ide dan kreativitas dalam pengeloaannya dan ikut menjaga dan melestarikan wisata yang kurang lebih sudah 3 tahun berdiri dengan desain yang cukup bagus dan menarik sebagai wahana rekreasi dan edukasi.

Pengaruh keberadaan obyek wisata ini buat pengunjung adalah memberikan informasi, wawasan dan sarana edukasi dan rekreasi untuk sebagai tempat berlibur yang indah dan menarik. Di lokasi Negeri Dongeng Blitar ini wisatawan akan menemukan suasana yang berbeda. Bukan hanya sebagai tempat rekreasi, tetapi juga sebagai wahana edukasi yang bermanfaat untuk anak dalam menggali ilmu. Dengan fasilitas lengkap, lokasi yang mudah dijangkau, serta harga tiket masuk Wisata Negeri Dongeng Blitar yang murah menjadi alasan tepat untuk berkunjung dii tempat wisata ini. Sebagai tempat wisata keluarga, negeri dongeng ini memiliki fasilitas yang cukup lengkap. Mulai dari fasilitas umum seperti toilet, area parkir, serta tempat ibadah dan masih banyak yang lain. Selain itu area wisata negeri dongeng ini ditanami pohon belimbing dan dihiasi dengan pemandangan kolam renang dan indahnya pegunungan yang menarik utntuk dikunjungi.

Selanjutnya yang menjadi icon serta magnet dari wisata ini adalah Landmark bangunan miniatur keajaiban dunia. Beberapa bangunan miniatur diantaranya; Candi Borobudur, Tugu Monas, Menara Piza, Piramida Giza Mesir, Kincir Angin Belanda, Colosseum Roma, Menara Eifel, Patung Liberty dan lainnya. Wisatawan dapat menikmati wahana yang lain yang sudah disediakan yang tentunya sangat menarik untuk dikunjungi.

\section{Strategi Pengembangan Objek Wisata Negeri Dongeng Sebagai Destinasi} Unggulan Berbasis Taman Wisata Miniatur Tempoe Doeloe

Berdasarkan hasil identifikasi maka didapatkan beberapa faktor penghambat dan pendukung dalam proses strategi pengembangan wisata Negeri Dongeng yaitu sebagai berikut:

\section{Faktor Penghambat}

\section{Dana yang Terbatas}

Faktor yang mempengaruhi tidak dan lancarnya pembangunan pariwisata di Negeri Dongeng adalah keterbatasan dana. Wisata Negeri Dongeng sesungguhnya milik swasta atau perseorangan. Wisata ini tidak melibatkan 
Pemerintah daerah dalam kaitannya sumber anggaran dana. Jadi ini dikelola dengan usaha kerjasama antara pihak desa dengan pengelola Negeri Dongeng sendiri. Terkait dengan dana memang menjadi kendala untuk proses pengembangan dan pembangunan.

\section{Status Kepemilikan Lahan}

Hal ini dikarenakan wisata Negeri Dongeng ini adalah milik swasta perseorangan. Lahan ini sebenarnya milik tanah warga (tanah Bengkok) yang tidak begitu berfungisecara maksimal. Oleh karena itu pihak masyarakat desa melakukan kerjasama dengan pihak wisata Negeri Dongeng untuk memfungsikan ini sebagai wahana wisata dengan sistem bagi hasil

\section{Faktor Pendukung}

\section{Objek Wisata Yang Baru Berdiri Tapi Sudah Dikenal Masyarakat}

Wisata Negeri Dongeng ini merupakan wisata yang baru berdiri tapi sudah dikenal oleh masyarakat luas di sekitar Jawa Timur, Hal itu mempengaruhi minat wisatawan yang ingin berkunjung ke Blitar untuk melihat wahana Negeri Dongeng. Wisata Negeri Dongeng sendiri berdiri sebagai wahana pertama yang bertemakan bangunan 7 keajaiban dunia yang menyuguhkan pemandangan yang menarik dan dilengkapi dengan sarana dan prasarana yang memadai.

\section{Peran Pemerintah Daerah Dan Masyarakat Sekitar}

Sebagaimana yang diketahui bahwa wisata negeri dongeng ini milik kepemilikan swasta, akan tetapi pemerintah daerah juga ikut mendukung proses pengembangannya dari Dinas Kebudayaan dan Pariwisata Daerah. Karena negeri dongeng merupakan salah satu faktor pendukung dalam pengembangan pariwisata daerah. Hal ini merupakan upaya untuk memajukan sector pariwisata di Kota/Kabupaten Blitar. Maka dari itu dibeberapa kesempatan pihak wisata negeri dongeng sendiri sering dikunjungi oleh Pemda sebagai upaya monitoring terkait perkembangan wisata ini dari waktu ke waktu. Selain itu juga sering pihak pengelola wisata ini untuk pergi keluar kota dengan pihak pariwisata yang lain untuk melakukan rapat dan kunjungan. Peran masyarakat juga sangat berpengaruh 
terhadap perkembangan wisata ini, karena mereka juga menyadari bahwa wisata ini sebagai ikon dan kebanggaan masyarakat setempat. Selain itu juga mereka diberikan fungsi untuk melakukan transaksi ekonomi di wisata tersebut dan juga sering dilibatkan ketika ada acara- acara penting.

\section{Mudahnya Koordinasi Antar Pihak Terkait}

Adanya hubungan baik antara pihak dinas kebudayaan dan pariwisata dengan pihak Negeri Dongeng, tentunya positif untuk keberlangsungan pengembangan wisata ini. Dengan adanya koordinasi dan komunikasi akan mempermudah pihak pengelola Negeri Dongeng sendiri untuk menjalin kerjasama di beberapa event resmi. Pihak Negeri Dongeng sendiri sering diibatkan ketika ada acara- acara resmi, rapat koordinasi dengan berbagai perwakilan pariwisata se Blitar Raya dalam rangka kemajuan sector pariwisata Kora/Kabupaten Blitar.

\section{Lokasi Geografis Objek Wisata}

Terkait dengan lokasi wisata Negeri Dongeng ini letaknya sangat strategis dan mudah dijangkau baik kendaraan pribadi atau transportasi umum. Selain itu wilayah wisata ini sangat menarik, karena didukung dengan pemandangan area persawahan dan gunung yang terdapat di sebelah barat wisata ini. Ini menjadi keunggulan dari wisata ini, karena berhasil mengkombinasikan antara wisata negeri dongeng sebagai wahana permainan dengan panorama alam disekitarnya.

Tabel 1. Analisis SWOT Wisata Negeri Dongeng Blitar

\begin{tabular}{|c|c|c|}
\hline & Kekuatan (Strenght) & Kelemahan (Weakness) \\
\hline IFE & \begin{tabular}{|l} 
- \\
Keragaman dan keunikan \\
wisata Negeri Dongeng. \\
Lokasi wilayah yang \\
strategis dengan panorama \\
alam yang menarik. \\
- Terdapat ikon wisata 7 \\
keajaiban dunia. \\
Wahana permainan yang \\
menarik dan bervariasi \\
sebagai tempat edukasi
\end{tabular} & $\begin{array}{ll}\text { - } & \text { Keterbatasan sarana } \\
\text { dan prasarana disekitar } \\
\text { lokasi wisata. } \\
\text { - } \\
\text { Keterbatasan akan } \\
\text { pentingnya pelayanan } \\
\text { publik dalam menarik } \\
\text { simpati pengunjung. } \\
\text { - Keterbatasan dana } \\
\text { untuk pengembangan } \\
\text { wisata }\end{array}$ \\
\hline EFE & $\begin{array}{l}\text { - Adanya wisata kebun } \\
\text { Blimbing sebagai } \\
\text { pelengkap sarana rekreasi. } \\
\text { - Milik swasta perseorangan }\end{array}$ & $\begin{array}{l}\text { Keterbatasan akan } \\
\text { pentingnya } \\
\text { menghasilkan produk } \\
\text { dari modal } \\
\text { pemanfaatan potensi }\end{array}$ \\
\hline
\end{tabular}




\begin{tabular}{|c|c|c|}
\hline & $\begin{array}{l}\text { dan tanah desa (kerja } \\
\text { sama). }\end{array}$ & \begin{tabular}{|l|} 
wisata. \\
Kepemilikan \\
swasta/perseorangan \\
sehingga masih belum \\
maksimal dalam \\
pengelolaannya. \\
\end{tabular} \\
\hline $\begin{array}{c}\text { Peluang } \\
\text { (Opportunity) }\end{array}$ & $\begin{array}{c}\text { Strategi Kekuatan \& Peluang } \\
\text { (SO) }\end{array}$ & $\begin{array}{c}\text { Strategi Kelemahan \& } \\
\text { Peluang (WO) }\end{array}$ \\
\hline \begin{tabular}{|l} 
Program promosi \\
wisata Negeri \\
Dongeng di berbagai \\
media dan pamphlet \\
Kondisi sosial \\
ekonomi Kota Blitar \\
yang relative stabil \\
Karakteristik \\
masyarakat yang \\
mayoritas bercocok \\
tanam dan beternak \\
Kebijakan \\
pemerintah \\
kabupaten/kota \\
dalam \\
mengembangkan \\
potensi wisata
\end{tabular} & \begin{tabular}{|l} 
1) $\begin{array}{l}\text { Kegiatan promosi potensi } \\
\text { wisata Negeri Dongeng pada } \\
\text { tingkat kabupaten kota } \\
\text { bahkan sampai tingkat } \\
\text { provinsi }\end{array}$ \\
2) \\
Lebih mengeksplor sumber \\
daya wisata ini menjadi \\
sebuah keragaman dan \\
keunikan tersendiri \\
3) \\
Perancangan kegiatan \\
outbond dan pembelajaran \\
sebagai sarana edukasi \\
4) Kerjasama dan \\
mengakomodir keterlibatan \\
pemerintah daerah pada \\
kegiatan pariwisata \\
5engupayakan untuk tetap \\
bertahan di saat pandemik \\
seperti ini agar wisata Negeri \\
Dongeng tetap eksis
\end{tabular} & 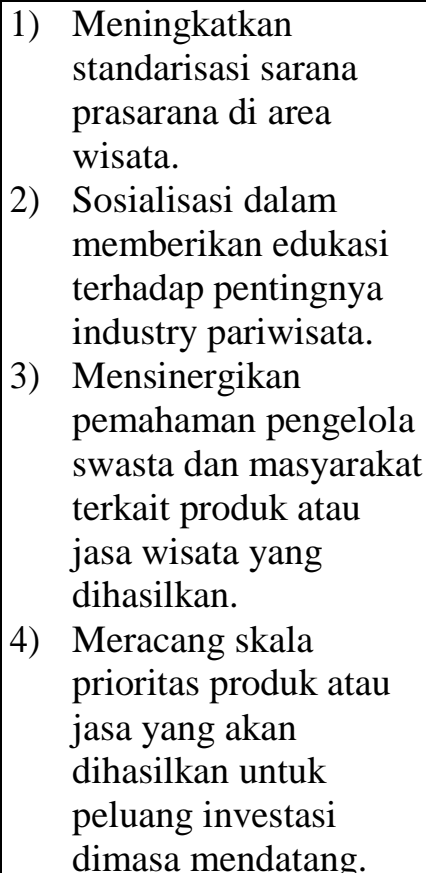 \\
\hline Ancaman (Threat) & $\begin{array}{c}\text { Strategi Kekuatan \& } \\
\text { Ancaman (ST) }\end{array}$ & $\begin{array}{c}\text { Strategi Kelemahan \& } \\
\text { Ancaman (WT) }\end{array}$ \\
\hline 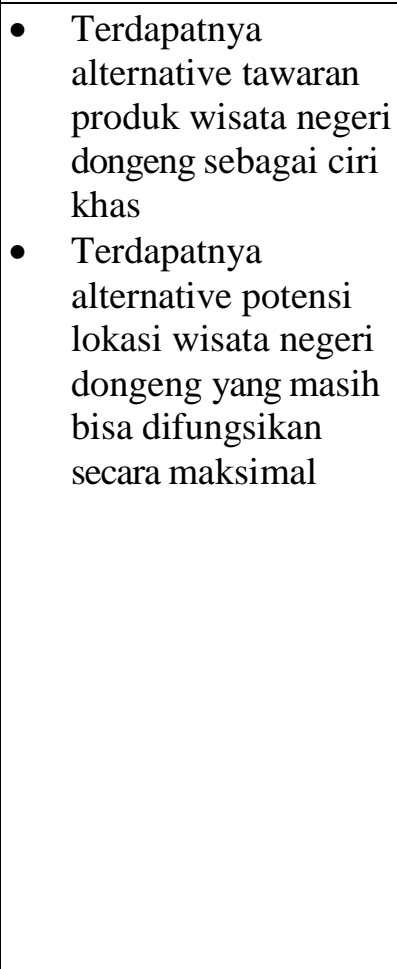 & 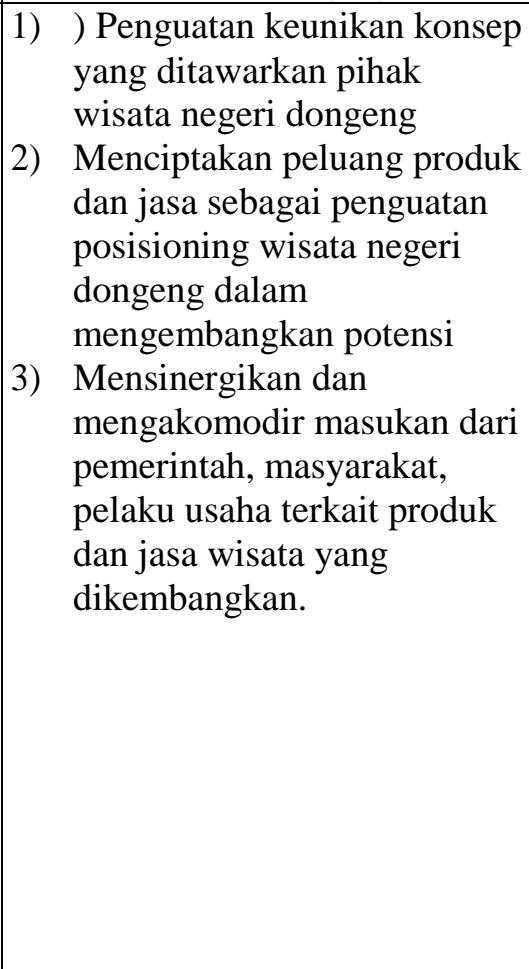 & 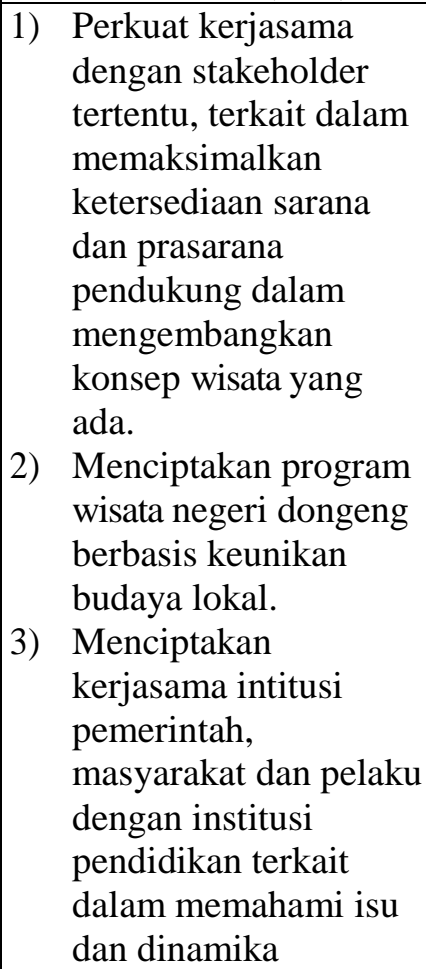 \\
\hline
\end{tabular}




\begin{tabular}{|l|l|l|}
\hline & & perubahan preferensi \\
& wisatawan terkait \\
konsep wisata negeri \\
dongeng yang \\
dikembangkan.
\end{tabular}

\section{HASIL DAN KESIMPULAN}

Wisata ini sangat memiliki potensi yang bagus untuk dikembangkan, karena selain ada bangunan atau tempat bermain yang menarik, juga ada pemandangan indah untuk dilihat. Nuansa alam yang dikombinasikan dengan sarana edukasi dan kebun blimbing menambah nilai eksotik dari wisata ini. Sayangnya di tahun ini wisata negeri dongeng tidak banyak memperoleh keuntungan karena pandemic covid 19 yang sangat memukul sector pariwisata khususnya.

Walaupun kondisinya seperti itu wisata ini tetap bertahan dengan anjuran protocol kesehatan. Walaupun tidak seramai biasanya tapi lambat laun cukup mengalami progress yang baik. Terlepas dari itu jika melihat dari penelitian ini dengan menggunakan analisis SWOT, wisata negeri dongeng sendiri juga masih memiliki kemungkinan untuk berkembang dan menaglami peningkatan. Maka dari itu dibutuhkan usaha dan kerja keras dari seluruh stakeholder abik pihak pengelola, masyarakatdan pemerintah daerah untuk mendukung dan berkontribusi terhadap kemajuan wisata ini. Dengan usaha ini akan menambah nilai optimis dan diyakini wisata ini akan mengalami peningkatan pendapatan yang maksimal untuk ke depan.

Dari hasil kesimpulan tersebut, adapun saran yang dapat disampaikan penulis adalah sebagai warga Blitar khususnya, kita patut berbangga dengan adanya wisata Negeri Dongeng ini. Sebagai wisata unggulan, wisata Negeri Dongeng ini dihimbau untuk tetap dilestarikan dan dan terus dipromosikan, sebagai wisata edukasi yang bermanfaat bagi para pengunjung yang datang untuk belajar dan menambah pengalaman dengan berbagi ilmu dan sarana rekreasi

Selain itu penulis menghimbau kepada semua pihak untuk ikut menjaga dan mengorbitkan wisata ini untuk dikembangkan lebih lanjut dalam upaya memperoleh hasil yang maksimal terkait dengan pengembangan potensi obyek wisata wisata Negeri Dongeng ini. Untuk itu perlu adanya saran dan masukan sebagai proses evaluasi agar karya ini dapat bermanfaat bagi semua pihak 
khusunya masyarakat kota Blitar.

\section{DAFTAR PUSTAKA}

Damayanti, I.A. (2009). Strategi Pengembangan Objek dan Daya Tarik Wisata Pelabuhan Buleleng. Jurnal Admisi \& Bisnis: Penerbit Jurusan Administrasi Niaga Politeknik Negeri Semarang. Semarang.

Fitra, Delita. (2012). Analisis Swot Untuk Strategi Pengembangan Obyek Wisata Pemandian Mual Mata Kecamatan Pematang Bandar Kabupaten Simalungun.. Jurnal Geografi: Universitas Negeri Medan, Vol. 9 no.1.

Rangkuti, F. 2016. Analisis SWOT-Teknik Membedah Kasus Bisnis. Jakarta: PT Gramedia Pustaka Utama.

Setya, Dega. (2018). Analisis Strategi Pengembangan Obyek Wisata Situs Jolotundo sebagai Obyek Wisata di Kawasan Peruntukan Pariwisata Budaya Kabupaten Mojokerto. Jurnal Pendidikan Geografi: Universitas Negeri Surabaya, Volume 5 Nomor 5 Tahun 2018.

Ridwan. (2012). Perencanaan dan Pengembangan Pariwisata. Jakarta: PT. Sofmedia.

Roestiyah, N. K. (2011). Strategi Belajar Mengajar Salah Satu Unsur Pelaksanaan Strategi Belajar Mengajar: Teknik Penyajian. Jakarta: Rineka Cipta

Sugiyono. 2014. Metode Penelitian Pendidikan Pendekatan Kuantitatif, Kualitatif dan $R \& D$. Bandung: Alfabeta

Sunaryo, B.. (2013). Kebijakan Pembangunan Destinasi Pariwisata Konsep dan Aplikasinya di Indonesia. Yogyakarta: Gava Media. 